\title{
Tannic Acid Induced Suicidal Erythrocyte Death
}

\author{
Majed Abed Tabea Herrmann Kousi Alzoubi Tatsiana Pakladok Florian Lang
}

Department of Physiology, University of Tübingen, Tübingen, Germany

\section{Key Words}

Phosphatidylserine $\cdot$ Tannic acid $•$ Calcium $•$ Cell volume $•$ Eryptosis

\begin{abstract}
Background: The polyphenol tannic acid with antioxidant and antimicrobial potency may trigger suicidal death of nucleated cells or apoptosis and thus may counteract tumor growth. In analogy to apoptosis of nucleated cells, erythrocytes may undergo eryptosis, a suicidal death characterized by cell shrinkage and cell membrane scrambling with appearance of phosphatidylserine at the erythrocyte surface. A major trigger of eryptosis is increase of cytosolic $\mathrm{Ca}^{2+}$-activity $\left(\left[\mathrm{Ca}^{2+}\right]_{i}\right)$. Erythrocytes could be sensitized to the eryptotic effect of cytosolic $\mathrm{Ca}^{2+}$ by ceramide. Methods: Cell volume has been estimated from forward scatter, phosphatidylserine abundance at the erythrocyte surface from annexin $\mathrm{V}$ binding, hemolysis from hemoglobin release, $\left[\mathrm{Ca}^{2+}\right]_{i}$ from Fluo3-fluorescence and ceramide utilizing fluorescent antibodies. Results: A $48 \mathrm{~h}$ treatment with tannic acid was followed by significant decrease of forward scatter $(\geq 1 \mu \mathrm{g} / \mathrm{ml})$ and significant increase of annexin-V-binding $(\geq 10 \mu \mathrm{g} / \mathrm{ml})$. Tannic acid did not significantly modify $\left[\mathrm{Ca}^{2+}\right]_{\mathrm{i}}$ (up to $50 \mu \mathrm{M}$ ) but significantly increased ceramide formation $(50 \mu \mathrm{M})$. The annexin-V-binding following tannic acid treatment $(50 \mu \mathrm{M})$ was significantly blunted in the nominal absence of extracellular $\mathrm{Ca}^{2+}$. Conclusions: Tannic acid stimulates eryptosis, an effect at least partially due to ceramide formation with subsequent sensitization of erythrocytes to cytosolic $\mathrm{Ca}^{2+}$.
\end{abstract}

Copyright (C) 2013 S. Karger AG, Basel

\section{Introduction}

Tannins including tannic acid are water soluble complex polyphenols with antioxidant [1-5], antimicrobial [1, 5-7] antiviral [1, 5, 6], anti-inflammatory [1, 8] and anti-tumor [9-12] properties. Further effects attributed to tannins and/or their metabolites include stimulation of blood clotting [1], decrease of blood pressure [1], modification of glucose metabolism [1], 
decrease of plasma lipids [1] and induction of liver necrosis [1]. Tannic acid may be useful in the treatment of malignancy [9-12]. The anticarcinogenic effect of tannic acid is at least partially due to stimulation of apoptosis [9-11, 13, 14]. Mechanisms invoked in tannic acid induced apoptosis include Fas-associated death domain (FADD) protein [15], proteasome activity [9, 14], inhibition of poly(ADP-ribose) glycohydrolase (PARG) expression [12], poly(ADP-ribose) (pADPr) [10, 12], cyclin-dependent kinase inhibitor p27(Kip1) [14], Bcl2 homologous antagonist/killer (Bak) [15], proapoptotic protein Bax [14], mitochondrial depolarization [10], release of apoptosis-inducing factor [10, 12], activation of caspases $[10,12]$ and DNA fragmentation $[10,13]$. Beyond that, tannic acid has both, antioxidant and oxidant potency [3].

Similar to nucleated cells, erythrocytes may enter suicidal death or eryptosis, which is characterized by cell membrane scrambling and cell shrinkage [16]. Eryptosis is triggered by increase of cytosolic $\mathrm{Ca}^{2+}$ concentration $\left(\left[\mathrm{Ca}^{2+}\right]_{\mathrm{i}}\right)$ resulting mainly from $\mathrm{Ca}^{2+}$ entry through $\mathrm{Ca}^{2+}$-permeable cation channels $[17,18]$. The channels involve the transient receptor potential channel TRPC6 [17] and are activated by oxidative stress [19]. An increase of $\left[\mathrm{Ca}^{2+}\right]_{\mathrm{i}}$ leads to activation of $\mathrm{Ca}^{2+}$-sensitive $\mathrm{K}^{+}$channels [20] with subsequent cell shrinkage due to $\mathrm{K}^{+}$exit, hyperpolarization, $\mathrm{Cl}^{-}$exit and thus cellular loss of $\mathrm{KCl}$ and osmotically driven water [21]. Increased $\left[\mathrm{Ca}^{2+}\right]_{i}$ further stimulates cell membrane scrambling with appearance of phosphatidylserine at the erythrocyte surface [22]. The cell membrane scrambling is sensitized for cytosolic $\mathrm{Ca}^{2+}$ by ceramide [23]. Further regulators of eryptosis include caspases [24-28], protein kinase C [29], AMP activated kinase AMPK [18], casein kinase [30, 31], cGMP-dependent protein kinase [32], Janus-activated kinase JAK3 [33], p38 kinase [34], PAK2 kinase [35] as well as sorafenib [36] and sunifinib [37] sensitive kinases.

Excessive eryptosis could result from exposure to xenobiotics [37-68] and complicates several diseases [16], such as diabetes [28, 69, 70], renal insufficiency [71], hemolytic uremic syndrome [72], sepsis [73], malaria [74], sickle cell disease [75], Wilson's disease [76], iron deficiency [77], malignancy [78], phosphate depletion [79] and metabolic syndrome [64].

Erythrocytes are devoid of mitochondria and nuclei, key elements in the machinery underlying apoptosis. Thus, analysis of eryptosis may uncover the significance of suicide mechanisms independent from those organelles. The present study thus explored, whether tannic acid triggers eryptosis. To this end, cell volume, phosphatidylserine abundance at the erythrocyte surface, $\left[\mathrm{Ca}^{2+}\right]_{\mathrm{i}^{\prime}}$ and ceramide abundance have been determined following exposure of human erythrocytes to Ringer solution without or with tannic acid.

\section{Materials and Methods}

\section{Erythrocytes, solutions and chemicals}

Leukocyte-depleted erythrocytes were kindly provided by the blood bank of the University of Tübingen. The study is approved by the ethics committee of the University of Tübingen (184/2003V). Erythrocytes were incubated in vitro at a hematocrit of $0.4 \%$ in Ringer solution containing (in mM) $125 \mathrm{NaCl}, 5 \mathrm{KCl}, 1 \mathrm{MgSO}_{4}$, $32 \mathrm{~N}$-2-hydroxyethylpiperazine-N-2-ethanesulfonic acid (HEPES), 5 glucose, $1 \mathrm{CaCl}_{2} ; \mathrm{pH} 7.4$ at $37^{\circ} \mathrm{C}$ for $48 \mathrm{~h}$. Where indicated, erythrocytes were exposed to tannic acid (Enzo, Lörrach, Germany) at the indicated concentrations. In $\mathrm{Ca}^{2+}$-free Ringer solution, $1 \mathrm{mM} \mathrm{CaCl}_{2}$ was substituted by $1 \mathrm{mM}$ glycol-bis(2-aminoethylether)$\mathrm{N}, \mathrm{N}, \mathrm{N}$ ',N'-tetraacetic acid (EGTA).

\section{FACS analysis of annexin-V-binding and forward scatter}

After incubation under the respective experimental condition, $50 \mu \mathrm{l}$ cell suspension was washed in Ringer solution containing $5 \mathrm{mM} \mathrm{CaCl}_{2}$ and then stained with Annexin-V-FITC (1:200 dilution; ImmunoTools, Friesoythe, Germany) in this solution at $37^{\circ} \mathrm{C}$ for 20 min under protection from light. In the following, the forward scatter (FSC) of the cells was determined and annexin-V fluorescence intensity was measured in FL-1 with an excitation wavelength of $488 \mathrm{~nm}$ and an emission wavelength of $530 \mathrm{~nm}$ on a FACS Calibur (BD, Heidelberg, Germany). 


\section{Measurement of intracellular $\mathrm{Ca}^{2+}$}

After incubation, erythrocytes were washed in Ringer solution and then loaded with Fluo-3/AM (Biotium, Hayward, USA) in Ringer solution containing $5 \mathrm{mM} \mathrm{CaCl}_{2}$ and $2 \mu \mathrm{M}$ Fluo-3/AM. The cells were incubated at $37^{\circ} \mathrm{C}$ for $30 \mathrm{~min}$ and washed twice in Ringer solution containing $5 \mathrm{mM} \mathrm{CaCl}_{2}$. The Fluo-3/AM-loaded erythrocytes were resuspended in $200 \mu \mathrm{l}$ Ringer. Then, $\mathrm{Ca}^{2+}$-dependent fluorescence intensity was measured in fluorescence channel FL-1 in FACS analysis.

\section{Measurement of hemolysis}

For the determination of hemolysis the samples were centrifuged ( $3 \mathrm{~min}$ at $400 \mathrm{~g}$, room temperature) after incubation, and the supernatants were harvested. As a measure of hemolysis, the hemoglobin $(\mathrm{Hb})$ concentration of the supernatant was determined photometrically at $405 \mathrm{~nm}$. The absorption of the supernatant of erythrocytes lysed in distilled water was defined as $100 \%$ hemolysis.

\section{Confocal microscopy and immunofluorescence}

For the detection of ceramide, erythrocytes were resuspended in PBS at $5 \times 107$ cells $/ \mathrm{ml}$ and $10 \mu \mathrm{l}$ was smeared onto a glass slide. After being air dried for $30 \mathrm{~min}$ and fixed with $4 \%$ paraformaldehyde/PBS for 10 min, the slides were rinsed 3 times for 5 min with PBS. Then, the slides were blocked with $10 \%$ normal goat serum (Invitrogen, Paisley, UK) for $1 \mathrm{~h}$ and again rinsed 3 times with PBS for $5 \mathrm{~min}$. The slides were incubated with mouse anti-ceramide antibody (diluted 1:100, Glycobiotech, Germany) at $4^{\circ} \mathrm{C}$ overnight and subsequently with fluorescence-labelled secondary Alexa Fluor 546 goat anti-mouse IgG (diluted 1:200, Invitrogen, UK) for $1 \mathrm{~h}$ at room temperature. The slides were mounted with Pro Long Gold antifade reagent (Invitrogen, UK). Images were taken on a Zeiss LSM5 EXCITER confocal laser scanning microscope (Carl Zeiss MicroImaging, Germany) with A-Plan 40x/1.2W.

\section{Determination of ceramide formation}

For the determination of ceramide abundance, a monoclonal antibody-based assay was used. After incubation, cells were stained for $1 \mathrm{~h}$ at $37^{\circ} \mathrm{C}$ with $1 \mu \mathrm{g} / \mathrm{ml}$ anti-ceramide antibody (clone MID 15B4, Alexis, Grünberg, Germany) in PBS containing 0.1\% bovine serum albumin (BSA) at a dilution of 1:5. The samples were washed twice with PBS-BSA. Subsequently, the cells were stained for 30 minutes with polyclonal fluoresceinisothiocyanate (FITC)-conjugated goat anti-mouse IgG and IgM specific antibody (Pharmingen, Hamburg, Germany) diluted 1:50 in PBS-BSA. Unbound secondary antibody was removed by repeated washing with PBS-BSA. Isotype control $\mathrm{F}\left(\mathrm{ab}^{\prime}\right)_{2} / \mathrm{IgG1}$ (BD Biosciences, Heidelberg, Germany) was used as negative control according to the manufacturer instructions. The samples were then analyzed by flow cytometric analysis in FL-1.

\section{Statistics}

Following flow cytometry, the average of $10^{4}$ cells has been calculated for each erythrocyte preparation. The arithmetic mean \pm the standard error of the mean (SEM) has been calculated from the averaged values obtained from the different erythrocyte preparations. Data are provided as arithmetic means \pm SEM. As indicated in the figure legends, statistical analysis was made using ANOVA with Tukey's test as post-test or unpaired Student's $\mathrm{t}$ test, where appropriate. $\mathrm{n}$ denotes the number of different erythrocyte specimens studied. Since different erythrocyte specimens used in distinct experiments are differently susceptible to triggers of eryptosis, the same erythrocyte specimens have been used for comparison of control and experimental conditions.

\section{Results}

The present study explored, whether treatment of human erythrocytes with tannic acid triggers the suicidal death of erythrocytes or eryptosis, which is characterized by cell shrinkage and cell membrane scrambling. To estimate erythrocyte volume, forward scatter was determined in FACS analysis. As shown in Fig. 1, a 48 hours exposure to tannic acid resulted in a decrease of forward scatter, an effect reaching statistical significance at $1 \mu \mathrm{M}$ tannic acid concentration. 

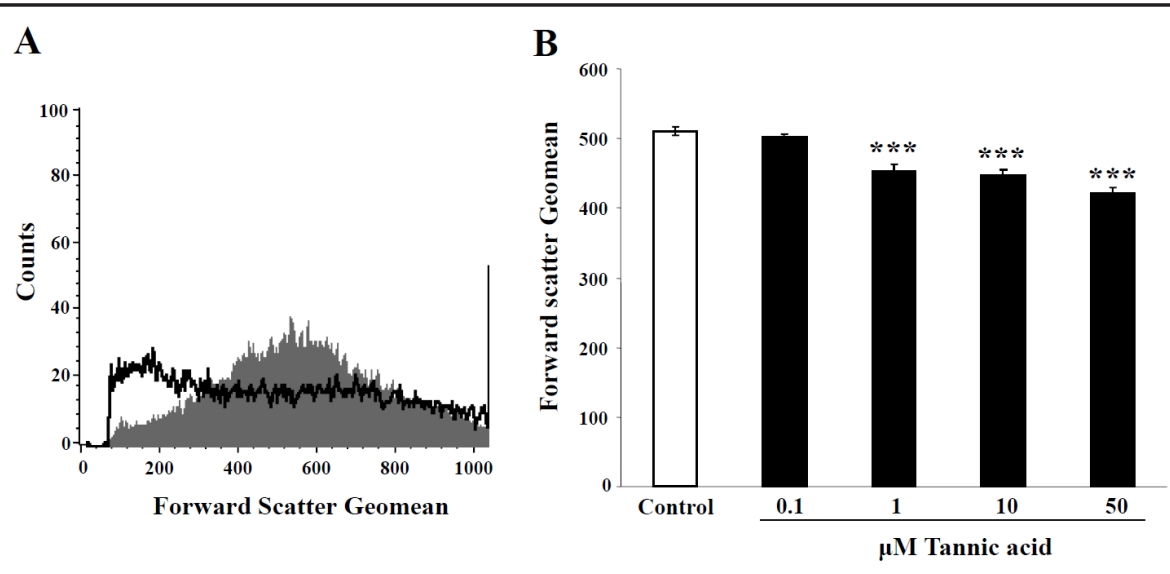

Fig. 1. Effect of tannic acid on erythrocyte forward scatter. A. Original histogram of forward scatter of erythrocytes following exposure for $48 \mathrm{~h}$ to Ringer solution without (grey shadow) and with (black line) presence of $50 \mu \mathrm{M}$ tannic acid. B. Arithmetic means \pm SEM $(n=8)$ of the normalized erythrocyte forward scatter (FSC) following incubation for $48 \mathrm{~h}$ to Ringer solution without (white bar) or with (black bars) tannic acid $(0.1-50 \mu \mathrm{M}){ }^{* * *}(\mathrm{p}<0.001)$ indicates significant difference from the absence of tannic acid (ANOVA).

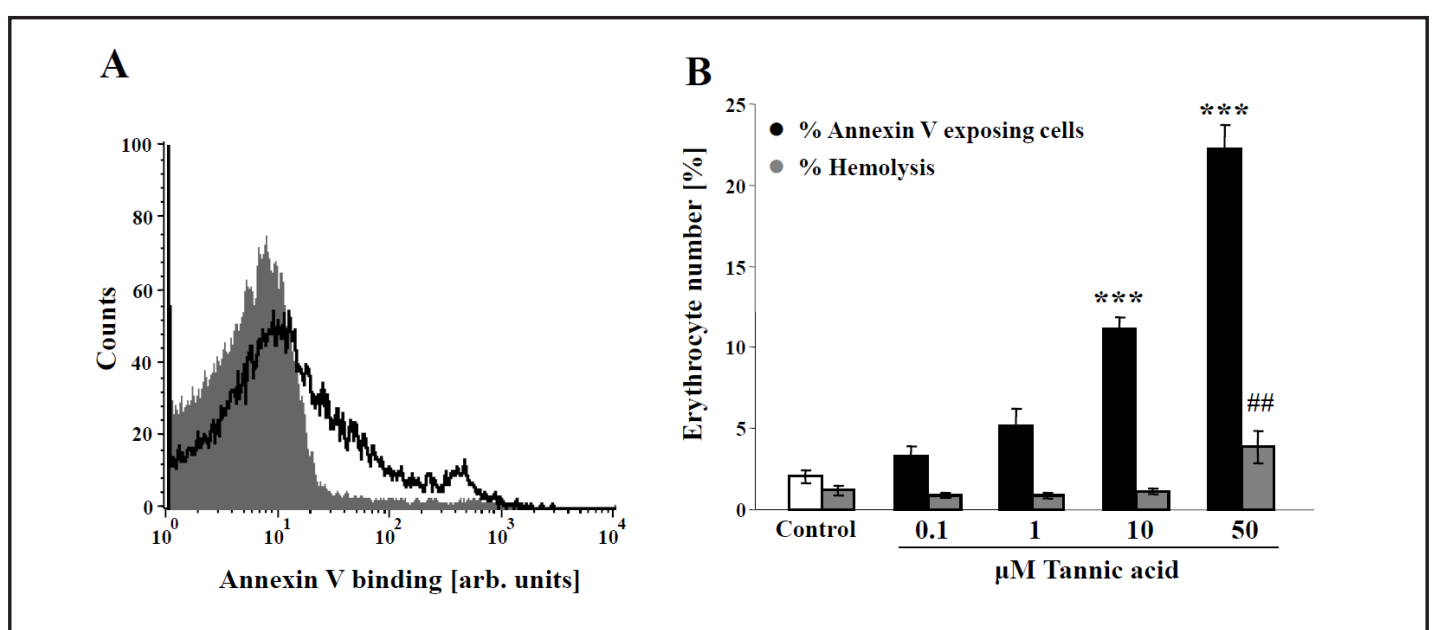

Fig. 2. Effect of tannic acid on phosphatidylserine exposure and hemolysis. A. Original histogram of annexinV-binding of erythrocytes following exposure for $48 \mathrm{~h}$ to Ringer solution without (grey shadow) and with (black line) presence of $50 \mu \mathrm{M}$ tannic acid. B. Arithmetic means \pm SEM $(n=8)$ of erythrocyte annexin-Vbinding following incubation for $48 \mathrm{~h}$ to Ringer solution without (white bar) or with (black bars) presence of tannic acid $(0.1-50 \mu \mathrm{M})$. For comparison, arithmetic means \pm SEM $(n=6)$ of the percentage of hemolysis is shown as grey bars. ${ }^{* * *}(\mathrm{p}<0.001)$ indicate significant differences from the absence of tannic acid (ANOVA), $\# \#(\mathrm{p}<0.01)$ indicates significant difference from the respective values in the presence of $\mathrm{Ca}^{2+}($ ANOVA).

In order to determine cell membrane scrambling with subsequent phosphatidylserine exposure at the cell surface, erythrocytes exposing phosphatidylserine at their surface were identified by annexin-V-binding in FACS analysis. As apparent from Fig. 2, a $48 \mathrm{~h}$ exposure to tannic acid was followed by an increase of annexin-V-binding. An arbitrary gate has been set to calculate the percentage of erythrocytes with excessive annexin $V$ binding. As illustrated in Fig. 2B, the percentage of erythrocytes with excessive annexin $\mathrm{V}$ binding increased following exposure to tannic acid, an effect reaching statistical significance at $\geq 10 \mu \mathrm{M}$ tannic acid concentrations.

A further series of experiments explored the effect of tannic acid on hemolysis, which was estimated by determination of hemoglobin in the supernatant. As a result, the 
A
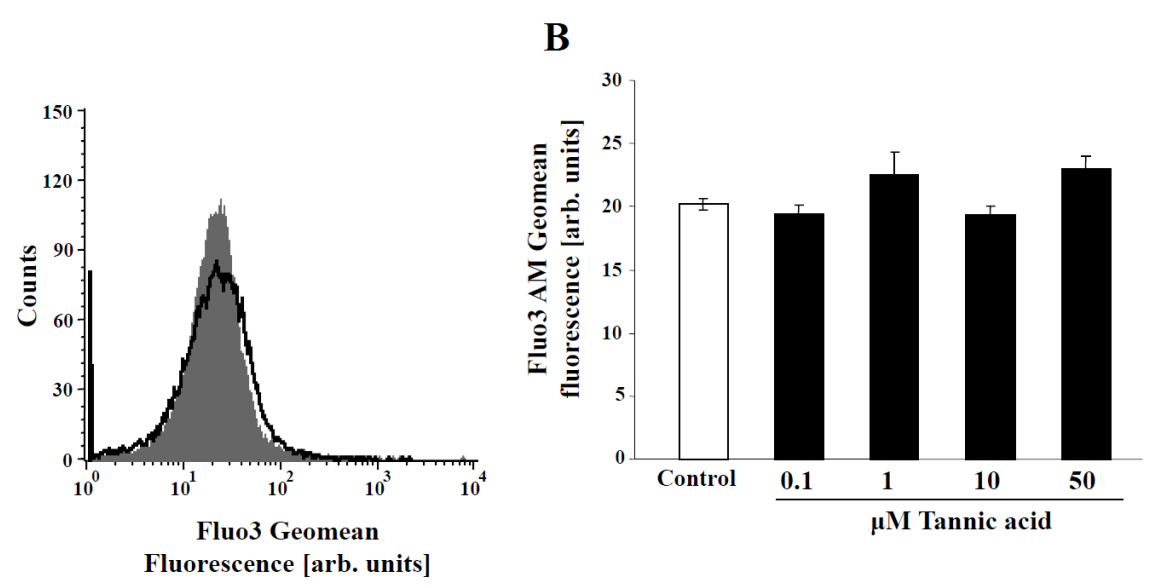

Fig. 3. Effect of tannic acid on erythrocyte cytosolic $\mathrm{Ca}^{2+}$ concentration. A. Original histogram of Fluo3 fluorescence in erythrocytes following exposure for $48 \mathrm{~h}$ to Ringer solution without (grey shadow) and with (black line) presence of $50 \mu \mathrm{M}$ tannic acid. B. Arithmetic means \pm SEM $(n=8)$ of the Fluo3 fluorescence (arbitrary units) in erythrocytes exposed for $48 \mathrm{~h}$ to Ringer solution without (white bar) or with (black bars) tannic acid $(0.1-50 \mu \mathrm{M})$.

Fig. 4. Effect of $\mathrm{Ca}^{2+}$ withdrawal on tannic acid induced annexin-V-binding. Arithmetic means \pm SEM $(n=5)$ of the percentage of annexin-V-binding erythrocytes after a $48 \mathrm{~h}$ treatment with Ringer solution without (white bar) or with (black bars) $50 \mu \mathrm{M}$ tannic acid in the presence (left bars, + Calcium) and absence (right bars, Calcium) of calcium. ${ }^{* * *}(\mathrm{p}<0.001)$ indicates significant difference from the absence of tannic acid (ANOVA), \#\# $(\mathrm{p}<0.01)$ indicates significant difference from the respective values in the presence of $\mathrm{Ca}^{2+}$ (ANOVA).

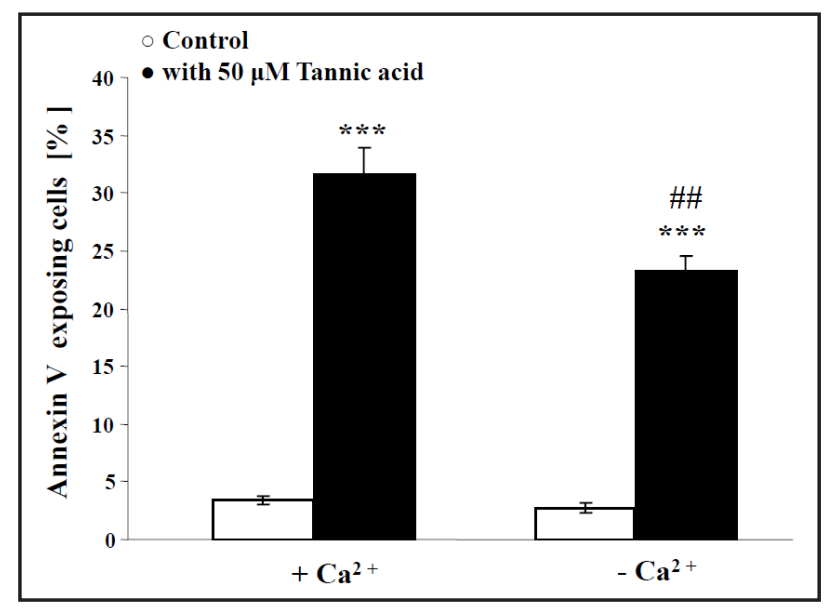

percentage of hemolyzed erythrocytes increased slightly but significantly following exposure of erythrocytes for $48 \mathrm{~h}$ to tannic acid (Fig. 2).

An additional series of experiments was performed to elucidate the mechanisms underlying the stimulation of tannic acid induced cell membrane scrambling. In order to determine cytosolic $\mathrm{Ca}^{2+}$ activity $\left(\left[\mathrm{Ca}^{2+}\right]_{\mathrm{i}}\right)$, the erythrocytes were incubated in Ringer solution in the absence or presence of tannic acid. The erythrocytes were subsequently loaded with Fluo3-AM and Fluo3 fluorescence determined in FACS analysis. As illustrated in Fig. 3, a 48 hours exposure of human erythrocytes to tannic acid concentrations did not significantly modify Fluo3 fluorescence.

In order to test, whether $\mathrm{Ca}^{2+}$ entry from the extracellular space was required for the effect of tannic acid on cell membrane scrambling, the erythrocytes were exposed to tannic acid for 48 hours in either the presence of $1 \mathrm{mM}$ extracellular $\mathrm{Ca}^{2+}$ or in the absence of extracellular $\mathrm{Ca}^{2+}$ and presence of the $\mathrm{Ca}^{2+}$ chelator EGTA $(1 \mathrm{mM})$. As shown in Fig. 4, the nominal absence of $\mathrm{Ca}^{2+}$ significantly blunted the effect of tannic acid on annexin-V-binding.

The observation that tannic acid induced cell membrane scrambling was dependent on the presence of $\mathrm{Ca}^{2+}$ but was not paralleled by an increase of $\left[\mathrm{Ca}^{2+}\right]_{i}$ was suggestive for an increase of $\mathrm{Ca}^{2+}$ sensitivity of cell membrane scrambling by tannic acid. As sensitivity of cell membrane scrambling to $\left[\mathrm{Ca}^{2+}\right]_{\mathrm{i}}$ is enhanced by ceramide, additional experiments 


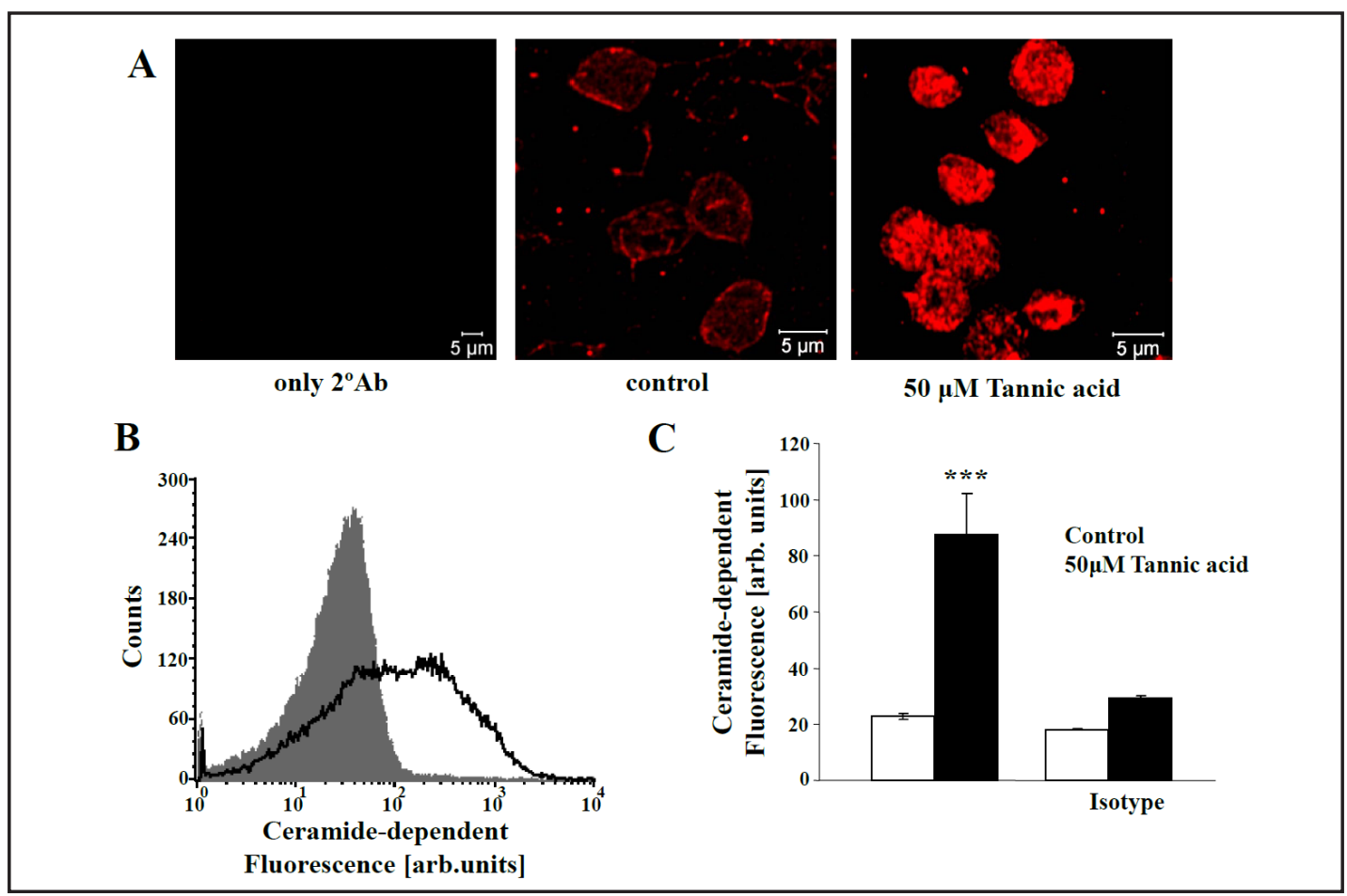

Fig. 5. Effect of tannic acid on ceramide formation. A. Confocal images of ceramide abundance at the erythrocyte surface prior to (middle panel) and after (right panel) a $48 \mathrm{~h}$ exposure to tannic acid ( $50 \mu \mathrm{M})$. The left panel shows erythrocytes stained only with secondary antibody as control. B. Original histogram of anticeramide FITC-fluorescence in erythrocytes following exposure for $48 \mathrm{~h}$ to Ringer solution without (grey shadow) or with (black line) $50 \mu \mathrm{M}$ tannic acid. C. Arithmetic means \pm SEM $(n=4)$ of ceramide abundance after a $48 \mathrm{~h}$ incubation in Ringer solution without (white bar) or with (black bars) tannic acid (50 $\mu \mathrm{M})$. Shown is the respective fluorescence intensity utilizing ceramide antibody (left bars) or isotype antibody (right bars). *** $(\mathrm{p}<0.001)$ indicates significant difference from control (absence of tannic acid) (ANOVA).

were performed to determine the effect of tannic acid on ceramide formation. To this end, ceramide abundance at the erythrocyte surface was quantified utilizing FITC-labeled anticeramide antibodies. As illustrated in Fig. 5, tannic acid significantly increased the ceramide abundance at the erythrocyte surface by $385 \%$. As a control, an isotyope antibody has been employed. As illustrated in Fig. 5C, tannic acid application did not significantly modify the fluorescence upon use of an isotype antibody.

\section{Discussion}

The present observations reveal a completely novel effect of tannic acid, i.e. the triggering of erythrocyte shrinkage and erythrocyte cell membrane scrambling, both hallmarks of eryptosis, the suicidal death of erythrocytes. The concentrations of tannic acid required for the induction of eryptosis are well in the range of tannic acid concentrations triggering apoptosis, the suicidal death of nucleated cells $[9,10,13,14]$. In vivo, reported dosages of tannic acid triggering methemoglobinemia include oral 2.0 to $4.6 \mathrm{~g}(1.1-2.7 \mathrm{mmol}) / \mathrm{kg} \mathrm{BW}$ in mice [80], oral $8 \mathrm{~g}$ (4.7 mmol) $/ \mathrm{kg} \mathrm{BW}$ in sheep [80], and intraperitoneal $0.1 \mathrm{~g}(60 \mu \mathrm{mol}) / \mathrm{kg} \mathrm{BW}$ in sheep [80].

The erythrocyte shrinkage following tannic acid treatment may result from activation of $\mathrm{Ca}^{2+}$ sensitive $\mathrm{K}^{+}$channels $[20,81]$, leading to $\mathrm{K}^{+}$exit, cell membrane hyperpolarization, potential driven $\mathrm{Cl}^{-}$exit and thus loss of cellular $\mathrm{KCl}$ along with the respective osmotically obliged water [21]. However, tannic acid did not significantly increase cytosolic $\mathrm{Ca}^{2+}$ activity. Thus, tannic 
acid must have activated the $\mathrm{K}^{+}$channels by some other mechanism. Alternatively, tannic acid activated other transport systems leading to cellular $\mathrm{KCl}$ loss, such as $\mathrm{KCl}$ symport. Further experiments are required to fully elucidate the mechanisms underlying tannic acid induced erythrocyte shrinkage.

As apparent from Fig. 1A, erythrocytes do not uniformly shrink following treatment with tannic acid. Instead, a subpopulation of erythrocytes underwent dramatic cell shrinkage, whereas another subpopulation of erythrocytes did not appreciably alter cell volume. The sensitivity of individual erythrocytes to triggers of eryptosis has previously been shown to be a function of erythrocyte age [45].

The phosphatidylserine exposure at the erythrocyte surface due to cell membrane scrambling following tannic acid treatment was strongly decreased in the absence of extracellular $\mathrm{Ca}^{2+}$ and was thus in large part dependent on the presence of extracellular $\mathrm{Ca}^{2+}$. However, tannic acid did not increase cytosolic $\mathrm{Ca}^{2+}$ activity. Thus, $\mathrm{Ca}^{2+}$ played a permissive role in the stimulation of cell membrane scrambling by tannic acid. The effect of tannic acid could thus have resulted from an increase of the $\mathrm{Ca}^{2+}$ sensitivity of cell membrane scrambling. The $\mathrm{Ca}^{2+}$ sensitivity could be enhanced by ceramide [23]. As a matter of fact, tannic acid treatment was followed by a marked increase of ceramide abundance at the erythrocyte surface. Ceramide production is presumably secondary to activation by acid sphingomyelinase [23]. Ceramide sensitizes the erythrocytes to the triggering of eryptosis by cytosolic $\mathrm{Ca}^{2+}$. Thus, the eventual outcome for a given cell depends on ceramide abundance, cytosolic $\mathrm{Ca}^{2+}$ activity and other factors including erythrocyte age. The decrease of extracellular $\mathrm{Ca}^{2+}$ concentration is expected to decrease eryptosis by lowering cytosolic $\mathrm{Ca}^{2+}$ activity. Moreover, tannic acid may fail to trigger eryptosis despite triggering of ceramide formation, if e.g. the erythrocyte is young and thus relatively resistant to eryptosis.

Consequences of erythrocyte cell membrane scrambling include the clearance of the affected erythrocytes from circulating blood [16]. As long as the loss of erythrocytes is matched by increased formation of new erythrocytes, the stimulation of eryptosis may remain without appreciable effect on blood count. The increased formation of erythrocytes is apparent from increased reticulocyte numbers in blood, which may thus point to enhanced erythrocyte turnover [16]. Clinically overt anemia develops as soon as the loss of circulating erythrocytes by eryptosis exceeds the formation of new erythrocytes [16].

Besides its potential effect on blood count, excessive eryptosis could compromise microcirculation. Phosphatidylserine exposing erythrocytes have been shown to adhere to endothelial CXCL16/SR-PSO of the vascular wall [82], which is expected to impede blood flow [82-87]. In addition, phosphatidylserine fosters blood clotting thus potentially leading to thrombosis [83, 88, 89].

Eryptosis may, however, not only be harmful. Eryptosis may precede and thus protect against hemolysis, which may result from excessive swelling of defective erythrocytes and eventually lead to cell membrane rupture with release of cellular hemoglobin [68]. The hemoglobin may be filtered in renal glomerula, precipitate in renal tubules and thus occlude nephrons [90]. The activation of $\mathrm{K}^{+}$channels in the course of eryptosis counteracts cell swelling [21] and the exposure of phosphatidylserine at the surface of eryptotic cells fosters engulfment of the defective erythrocytes by phagocytosing cells prior to hemolysis [68].

In conclusion, tannic acid stimulates cell membrane scrambling and cell shrinkage, an effect partially due to ceramide formation with subsequent sensitization of erythrocytes to cytosolic $\mathrm{Ca}^{2+}$.

\section{Acknowledgements}

The authors acknowledge the meticulous preparation of the manuscript by Ali Soleimanpour. This study was supported by the Deutsche Forschungsgemeinschaft and Open Access Publishing Fund of Tuebingen University. 


\section{References}

1 Chung KT, Wong TY, Wei CI, Huang YW, Lin Y: Tannins and human health: a review. Crit Rev Food Sci Nutr 1998;38:421-464.

2 Hamiza 00, Rehman MU, Tahir M, Khan R, Khan AQ, Lateef A, Ali F, Sultana S: Amelioration of 1,2 Dimethylhydrazine (DMH) induced colon oxidative stress, inflammation and tumor promotion response by tannic acid in Wistar rats. Asian Pac J Cancer Prev 2012;13:4393-4402.

3 Khan NS, Ahmad A, Hadi SM: Anti-oxidant, pro-oxidant properties of tannic acid and its binding to DNA. Chem Biol Interact 2000;125:177-189.

-4 Koleckar V, Kubikova K, Rehakova Z, Kuca K, Jun D, Jahodar L, Opletal L: Condensed and hydrolysable tannins as antioxidants influencing the health. Mini Rev Med Chem 2008;8:436-447.

-5 Serrano J, Puupponen-Pimia R, Dauer A, Aura AM, Saura-Calixto F: Tannins: current knowledge of food sources, intake, bioavailability and biological effects. Mol Nutr Food Res 2009;53:S310-329.

6 Buzzini P, Arapitsas P, Goretti M, Branda E, Turchetti B, Pinelli P, Ieri F, Romani A: Antimicrobial and antiviral activity of hydrolysable tannins. Mini Rev Med Chem 2008;8:1179-1187.

7 Payne DE, Martin NR, Parzych KR, Rickard AH, Underwood A, Boles BR: Tannic acid inhibits Staphylococcus aureus surface colonization in an IsaA dependent manner. Infect Immun 2013;81:496-504.

8 Holderness J, Hedges JF, Daughenbaugh K, Kimmel E, Graff J, Freedman B, Jutila MA: Response of gammadelta T Cells to plant-derived tannins. Crit Rev Immunol 2008;28:377-402.

$\checkmark 9$ Chang TL, Wang CH: Combination of quercetin and tannic acid in inhibiting 26S proteasome affects S5a and $20 \mathrm{~S}$ expression and accumulation of ubiquitin resulted in apoptosis in cancer chemoprevention. Biol Chem 2012;10.1515/hsz-2012-0277.

10 Chen KS, Hsiao YC, Kuo DY, Chou MC, Chu SC, Hsieh YS, Lin TH: Tannic acid-induced apoptosis and -enhanced sensitivity to arsenic trioxide in human leukemia HL-60 cells. Leuk Res 2009;33:297-307.

11 Khan NS, Hadi SM: Structural features of tannic acid important for DNA degradation in the presence of $\mathrm{Cu}(\mathrm{II})$. Mutagenesis 1998;13:271-274.

12 Sun Y, Zhang T, Wang B, Li H, Li P: Tannic acid, an inhibitor of poly(ADP-ribose) glycohydrolase, sensitizes ovarian carcinoma cells to cisplatin. Anticancer Drugs 2012;23:979-990.

13 Labieniec M, Gabryelak T: Oxidatively modified proteins and DNA in digestive gland cells of the fresh-water mussel Unio tumidus in the presence of tannic acid and its derivatives. Mutat Res 2006;603:48-55.

14 Nam S, Smith DM, Dou QP: Tannic acid potently inhibits tumor cell proteasome activity, increases p27 and Bax expression, and induces G1 arrest and apoptosis. Cancer Epidemiol Biomarkers Prev 2001;10:10831088.

15 Cosan D, Soyocak A, Basaran A, Degirmenci I, Gunes HV: The effects of resveratrol and tannic acid on apoptosis in colon adenocarcinoma cell line. Saudi Med J 2009;30:191-195.

16 Lang F, Gulbins E, Lerche H, Huber SM, Kempe DS, Föller M: Eryptosis, a window to systemic disease. Cell Physiol Biochem 2008;22:373-380.

17 Foller M, Kasinathan RS, Koka S, Lang C, Shumilina E, Birnbaumer L, Lang F, Huber SM: TRPC6 contributes to the $\mathrm{Ca}^{2+}$ leak of human erythrocytes. Cell Physiol Biochem 2008;21:183-192.

18 Foller M, Sopjani M, Koka S, Gu S, Mahmud H, Wang K, Floride E, Schleicher E, Schulz E, Munzel T, Lang F: Regulation of erythrocyte survival by AMP-activated protein kinase. FASEB J 2009;23:1072-1080.

19 Brand VB, Sandu CD, Duranton C, Tanneur V, Lang KS, Huber SM, Lang F: Dependence of Plasmodium falciparum in vitro growth on the cation permeability of the human host erythrocyte. Cell Physiol Biochem 2003;13:347-356.

20 Brugnara C, de Franceschi L, Alper SL: Inhibition of $\mathrm{Ca}^{2+}$-dependent $\mathrm{K}^{+}$transport and cell dehydration in sickle erythrocytes by clotrimazole and other imidazole derivatives. J Clin Invest 1993;92:520-526.

21 Lang PA, Kaiser S, Myssina S, Wieder T, Lang F, Huber SM: Role of $\mathrm{Ca}^{2+}$-activated $\mathrm{K}^{+}$channels in human erythrocyte apoptosis. Am J Physiol Cell Physiol 2003;285:C1553-C1560.

22 Berg CP, Engels IH, Rothbart A, Lauber K, Renz A, Schlosser SF, Schulze-Osthoff K, Wesselborg S: Human mature red blood cells express caspase- 3 and caspase-8, but are devoid of mitochondrial regulators of apoptosis. Cell Death Differ 2001;8:1197-1206.

23 Lang F, Gulbins E, Lang PA, Zappulla D, Foller M: Ceramide in suicidal death of erythrocytes. Cell Physiol Biochem 2010;26:21-28. 
24 Bhavsar SK, Bobbala D, Xuan NT, Foller M, Lang F: Stimulation of suicidal erythrocyte death by alpha-lipoic acid. Cell Physiol Biochem 2010;26:859-868.

-25 Foller M, Huber SM, Lang F: Erythrocyte programmed cell death. IUBMB Life 2008;60:661-668.

-26 Foller M, Mahmud H, Gu S, Wang K, Floride E, Kucherenko Y, Luik S, Laufer S, Lang F: Participation of leukotriene C(4) in the regulation of suicidal erythrocyte death. J Physiol Pharmacol 2009;60:135-143.

27 Lau IP, Chen H, Wang J, Ong HC, Leung KC, Ho HP, Kong SK: In vitro effect of CTAB- and PEG-coated gold nanorods on the induction of eryptosis/erythroptosis in human erythrocytes. Nanotoxicology 2012;6:847856.

28 Maellaro E, Leoncini S, Moretti D, Del Bello B, Tanganelli I, De Felice C, Ciccoli L: Erythrocyte caspase-3 activation and oxidative imbalance in erythrocytes and in plasma of type 2 diabetic patients. Acta Diabetol 2013;50:489-495.

-29 Klarl BA, Lang PA, Kempe DS, Niemoeller OM, Akel A, Sobiesiak M, Eisele K, Podolski M, Huber SM, Wieder T, Lang F: Protein kinase C mediates erythrocyte "programmed cell death" following glucose depletion. Am J Physiol Cell Physiol 2006;290:C244-C253.

-30 Kucherenko Y, Zelenak C, Eberhard M, Qadri SM, Lang F: Effect of casein kinase 1alpha activator pyrvinium pamoate on erythrocyte ion channels. Cell Physiol Biochem 2012;30:407-417.

-31 Zelenak C, Eberhard M, Jilani K, Qadri SM, Macek B, Lang F: Protein kinase CK1alpha regulates erythrocyte survival. Cell Physiol Biochem 2012;29:171-180.

-32 Foller M, Feil S, Ghoreschi K, Koka S, Gerling A, Thunemann M, Hofmann F, Schuler B, Vogel J, Pichler B, Kasinathan RS, Nicolay JP, Huber SM, Lang F, Feil R: Anemia and splenomegaly in cGKI-deficient mice. Proc Natl Acad Sci USA 2008;105:6771-6776.

33 Bhavsar SK, Gu S, Bobbala D, Lang F: Janus kinase 3 is expressed in erythrocytes, phosphorylated upon energy depletion and involved in the regulation of suicidal erythrocyte death. Cell Physiol Biochem 2011;27:547-556.

-34 Gatidis S, Zelenak C, Fajol A, Lang E, Jilani K, Michael D, Qadri SM, Lang F: p38 MAPK activation and function following osmotic shock of erythrocytes. Cell Physiol Biochem 2011;28:1279-1286.

35 Zelenak C, Foller M, Velic A, Krug K, Qadri SM, Viollet B, Lang F, Macek B: Proteome analysis of erythrocytes lacking AMP-activated protein kinase reveals a role of PAK2 kinase in eryptosis. J Proteome Res 2011;10:1690-1697.

-36 Lupescu A, Shaik N, Jilani K, Zelenak C, Lang E, Pasham V, Zbidah M, Plate A, Bitzer M, Foller M, Qadri SM, Lang F: Enhanced Erythrocyte Membrane Exposure of Phosphatidylserine Following Sorafenib Treatment: An in vivo and in vitro Study. Cell Physiol Biochem 2012;30:876-888.

37 Shaik N, Lupescu A, Lang F: Sunitinib-sensitive suicidal erythrocyte death. Cell Physiol Biochem 2012;30:512-522.

38 Abed M, Towhid ST, Mia S, Pakladok T, Alesutan I, Borst O, Gawaz M, Gulbins E, Lang F: Sphingomyelinaseinduced adhesion of eryptotic erythrocytes to endothelial cells. Am J Physiol Cell Physiol 2012;303:C991999.

-39 Abed M, Towhid ST, Shaik N, Lang F: Stimulation of suicidal death of erythrocytes by rifampicin. Toxicology 2012;10.1016/j.tox.2012.10.006

40 Bottger E, Multhoff G, Kun JF, Esen M: Plasmodium falciparum-infected erythrocytes induce granzyme B by NK cells through expression of host-Hsp70. PLoS One 2012;7:e33774.

41 Felder KM, Hoelzle K, Ritzmann M, Kilchling T, Schiele D, Heinritzi K, Groebel K, Hoelzle LE: Hemotrophic mycoplasmas induce programmed cell death in red blood cells. Cell Physiol Biochem 2011;27:557-564.

-42 Firat U, Kaya S, Cim A, Buyukbayram H, Gokalp 0, Dal MS, Tamer MN: Increased caspase-3 immunoreactivity of erythrocytes in STZ diabetic rats. Exp Diabetes Res 2012;2012:316384.

43 Ganesan S, Chaurasiya ND, Sahu R, Walker LA, Tekwani BL: Understanding the mechanisms for metabolism-linked hemolytic toxicity of primaquine against glucose 6-phosphate dehydrogenase deficient human erythrocytes: evaluation of eryptotic pathway. Toxicology 2012;294:54-60.

44 Gao M, Cheung KL, Lau IP, Yu WS, Fung KP, Yu B, Loo JF, Kong SK: Polyphyllin D induces apoptosis in human erythrocytes through $\mathrm{Ca}^{2+}$ rise and membrane permeabilization. Arch Toxicol 2012;86:741-752.

-45 Ghashghaeinia M, Cluitmans JC, Akel A, Dreischer P, Toulany M, Koberle M, Skabytska Y, Saki M, Biedermann T, Duszenko M, Lang F, Wieder T, Bosman GJ: The impact of erythrocyte age on eryptosis. Br J Haematol 2012;157:606-614. 
Abed/Herrmann/Alzoubi/Pakladok/Lang: Tannic Acid-Induced Eryptosis

46 Ghashghaeinia M, Toulany M, Saki M, Bobbala D, Fehrenbacher B, Rupec R, Rodemann HP, Ghoreschi K, Rocken M, Schaller M, Lang F, Wieder T: The NFkB pathway inhibitors Bay 11-7082 and parthenolide induce programmed cell death in anucleated Erythrocytes. Cell Physiol Biochem 2011;27:45-54.

47 Jilani K, Lupescu A, Zbidah M, Abed M, Shaik N, Lang F: Enhanced Apoptotic Death of Erythrocytes Induced by the Mycotoxin Ochratoxin A. Kidney Blood Press Res 2012;36:107-118.

48 Jilani K, Lupescu A, Zbidah M, Shaik N, Lang F: Withaferin A-stimulated $\mathrm{Ca}^{2+}$ entry, ceramide formation and suicidal death of erythrocytes. Toxicol In Vitro 2012;10.1016/j.tiv.2012.09.004

-49 Kucherenko YV, Lang F: Inhibitory Effect of Furosemide on Non-Selective Voltage-Independent Cation Channels in Human Erythrocytes. Cell Physiol Biochem 2012;30:863-875.

50 Lang E, Jilani K, Zelenak C, Pasham V, Bobbala D, Qadri SM, Lang F: Stimulation of suicidal erythrocyte death by benzethonium. Cell Physiol Biochem 2011;28:347-354.

51 Lang E, Qadri SM, Jilani K, Zelenak C, Lupescu A, Schleicher E, Lang F: Carbon monoxide-sensitive apoptotic death of erythrocytes. Basic Clin Pharmacol Toxicol 2012;111:348-355.

52 Lang F, Qadri SM: Mechanisms and significance of eryptosis, the suicidal death of erythrocytes. Blood Purif 2012;33:125-130.

53 Lupescu A, Jilani K, Zbidah M, Lang E, Lang F: Enhanced Ca ${ }^{2+}$ Entry, Ceramide Formation, and Apoptotic Death of Erythrocytes Triggered by Plumbagin. J Nat Prod 2012;10.1021/np300611r.

54 Lupescu A, Jilani K, Zbidah M, Lang F: Induction of apoptotic erythrocyte death by rotenone. Toxicology 2012;300:132-137.

55 Lupescu A, Jilani K, Zelenak C, Zbidah M, Qadri SM, Lang F: Hexavalent chromium-induced erythrocyte membrane phospholipid asymmetry. Biometals 2012;25:309-318.

56 Polak-Jonkisz D, Purzyc L: Ca Influx versus Efflux during Eryptosis in Uremic Erythrocytes. Blood Purif 2012;34:209-210.

57 Qadri SM, Bauer J, Zelenak C, Mahmud H, Kucherenko Y, Lee SH, Ferlinz K, Lang F: Sphingosine but not sphingosine-1-phosphate stimulates suicidal erythrocyte death. Cell Physiol Biochem 2011;28:339-346.

58 Qadri SM, Kucherenko Y, Lang F: Beauvericin induced erythrocyte cell membrane scrambling. Toxicology 2011;283:24-31.

-59 Qadri SM, Kucherenko Y, Zelenak C, Jilani K, Lang E, Lang F: Dicoumarol activates Ca ${ }^{2+}$-permeable cation channels triggering erythrocyte cell membrane scrambling. Cell Physiol Biochem 2011;28:857-864.

60 Qian EW, Ge DT, Kong SK: Salidroside protects human erythrocytes against hydrogen peroxide-induced apoptosis. J Nat Prod 2012;75:531-537.

61 Shaik N, Zbidah M, Lang F: Inhibition of $\mathrm{Ca}^{2+}$ entry and suicidal erythrocyte death by naringin. Cell Physiol Biochem 2012;30:678-686.

62 Vota DM, Maltaneri RE, Wenker SD, Nesse AB, Vittori DC: Differential Erythropoietin Action upon Cells Induced to Eryptosis by Different Agents. Cell Biochem Biophys 2012;10.1007/s12013-012-9408-4

63 Weiss E, Cytlak UM, Rees DC, Osei A, Gibson JS: Deoxygenation-induced and $\mathrm{Ca}^{2+}$ dependent phosphatidylserine externalisation in red blood cells from normal individuals and sickle cell patients. Cell Calcium 2012;51:51-56.

64 Zappulla D: Environmental stress, erythrocyte dysfunctions, inflammation, and the metabolic syndrome: adaptations to CO2 increases? J Cardiometab Syndr 2008;3:30-34.

65 Zbidah M, Lupescu A, Jilani K, Lang F: Stimulation of Suicidal Erythrocyte Death by Fumagillin. Basic Clin Pharmacol Toxicol 2012;10.1111/bcpt.12033.

66 Zbidah M, Lupescu A, Shaik N, Lang F: Gossypol-induced suicidal erythrocyte death. Toxicology 2012;10.1016/j.tox.2012.09.010.

67 Zelenak C, Pasham V, Jilani K, Tripodi PM, Rosaclerio L, Pathare G, Lupescu A, Faggio C, Qadri SM, Lang F: Tanshinone IIA stimulates erythrocyte phosphatidylserine exposure. Cell Physiol Biochem 2012;30:282294.

68 Lang E, Qadri SM, Lang F: Killing me softly - suicidal erythrocyte death. Int J Biochem Cell Biol 2012;44:1236-1243.

69 Calderon-Salinas JV, Munoz-Reyes EG, Guerrero-Romero JF, Rodriguez-Moran M, Bracho-Riquelme RL, Carrera-Gracia MA, Quintanar-Escorza MA: Eryptosis and oxidative damage in type 2 diabetic mellitus patients with chronic kidney disease. Mol Cell Biochem 2011;357:171-179. 
70 Nicolay JP, Schneider J, Niemoeller OM, Artunc F, Portero-Otin M, Haik G Jr, Thornalley PJ, Schleicher E, Wieder T, Lang F: Stimulation of suicidal erythrocyte death by methylglyoxal. Cell Physiol Biochem 2006;18:223-232.

71 Myssina S, Huber SM, Birka C, Lang PA, Lang KS, Friedrich B, Risler T, Wieder T, Lang F: Inhibition of erythrocyte cation channels by erythropoietin. J Am Soc Nephrol 2003;14:2750-2757.

72 Lang PA, Beringer O, Nicolay JP, Amon O, Kempe DS, Hermle T, Attanasio P, Akel A, Schafer R, Friedrich B, Risler T, Baur M, Olbricht CJ, Zimmerhackl LB, Zipfel PF, Wieder T, Lang F: Suicidal death of erythrocytes in recurrent hemolytic uremic syndrome. J Mol Med 2006;84:378-388.

73 Kempe DS, Akel A, Lang PA, Hermle T, Biswas R, Muresanu J, Friedrich B, Dreischer P, Wolz C, Schumacher U, Peschel A, Gotz F, Doring G, Wieder T, Gulbins E, Lang F: Suicidal erythrocyte death in sepsis. J Mol Med 2007;85:269-277.

74 Foller M, Bobbala D, Koka S, Huber SM, Gulbins E, Lang F: Suicide for survival--death of infected erythrocytes as a host mechanism to survive malaria. Cell Physiol Biochem 2009;24:133-140.

75 Lang PA, Kasinathan RS, Brand VB, Duranton C, Lang C, Koka S, Shumilina E, Kempe DS, Tanneur V, Akel A, Lang KS, Foller M, Kun JF, Kremsner PG, Wesselborg S, Laufer S, Clemen CS, Herr C, Noegel AA, Wieder T, Gulbins E, Lang F, Huber SM: Accelerated clearance of Plasmodium-infected erythrocytes in sickle cell trait and annexin-A7 deficiency. Cell Physiol Biochem 2009;24:415-428.

76 Lang PA, Schenck M, Nicolay JP, Becker JU, Kempe DS, Lupescu A, Koka S, Eisele K, Klarl BA, Rubben H, Schmid KW, Mann K, Hildenbrand S, Hefter H, Huber SM, Wieder T, Erhardt A, Haussinger D, Gulbins E, Lang F: Liver cell death and anemia in Wilson disease involve acid sphingomyelinase and ceramide. Nat Med 2007;13:164-170.

77 Kempe DS, Lang PA, Duranton C, Akel A, Lang KS, Huber SM, Wieder T, Lang F: Enhanced programmed cell death of iron-deficient erythrocytes. FASEB J 2006;20:368-370.

78 Qadri SM, Mahmud H, Lang E, Gu S, Bobbala D, Zelenak C, Jilani K, Siegfried A, Foller M, Lang F: Enhanced suicidal erythrocyte death in mice carrying a loss-of-function mutation of the adenomatous polyposis coli gene. J Cell Mol Med 2012;16:1085-1093.

79 Birka C, Lang PA, Kempe DS, Hoefling L, Tanneur V, Duranton C, Nammi S, Henke G, Myssina S, Krikov M, Huber SM, Wieder T, Lang F: Enhanced susceptibility to erythrocyte "apoptosis" following phosphate depletion. Pflugers Arch 2004;448:471-477.

80 Zhu J, Filippich LJ, MT AL: Tannic acid intoxication in sheep and mice. Res Vet Sci 1992;53:280-292.

81 Bookchin RM, Ortiz OE, Lew VL: Activation of calcium-dependent potassium channels in deoxygenated sickled red cells. Prog Clin Biol Res 1987;240:193-200.

82 Borst O, Abed M, Alesutan I, Towhid ST, Qadri SM, Foller M, Gawaz M, Lang F: Dynamic adhesion of eryptotic erythrocytes to endothelial cells via CXCL16/SR-PSOX. Am J Physiol Cell Physiol 2012;302:C644-C651.

-83 Andrews DA, Low PS: Role of red blood cells in thrombosis. Curr Opin Hematol 1999;6:76-82.

84 Closse C, Dachary-Prigent J, Boisseau MR: Phosphatidylserine-related adhesion of human erythrocytes to vascular endothelium. Br J Haematol 1999;107:300-302.

85 Gallagher PG, Chang SH, Rettig MP, Neely JE, Hillery CA, Smith BD, Low PS: Altered erythrocyte endothelial adherence and membrane phospholipid asymmetry in hereditary hydrocytosis. Blood 2003;101:46254627.

86 Pandolfi A, Di Pietro N, Sirolli V, Giardinelli A, Di Silvestre S, Amoroso L, Di Tomo P, Capani F, Consoli A, Bonomini M: Mechanisms of uremic erythrocyte-induced adhesion of human monocytes to cultured endothelial cells. J Cell Physiol 2007;213:699-709.

87 Wood BL, Gibson DF, Tait JF: Increased erythrocyte phosphatidylserine exposure in sickle cell disease: flowcytometric measurement and clinical associations. Blood 1996;88:1873-1880.

$\$ 88$ Chung SM, Bae ON, Lim KM, Noh JY, Lee MY, Jung YS, Chung JH: Lysophosphatidic acid induces thrombogenic activity through phosphatidylserine exposure and procoagulant microvesicle generation in human erythrocytes. Arterioscler Thromb Vasc Biol 2007;27:414-421.

89 Zwaal RF, Comfurius P, Bevers EM: Surface exposure of phosphatidylserine in pathological cells. Cell Mol Life Sci 2005;62:971-988.

$\$ 90$ Harrison HE, Bunting H, Ordway NK, Albrink WS: The Pathogenesis of the Renal Injury Produced in the Dog by Hemoglobin or Methemoglobin. J Exp Med 1947;86:339-356. 